\title{
Calculating Cognitive Dispersion of the curriculum
}

\section{Calculando la Dispersión Cognitiva del curriculum}

MUÑOZ-LÓPEZ, Temístocles*†, HERNÁNDEZ CUETO, Jaquelina Lizet, MORÁN-DELGADO, Gabriela and MARTÍNEZ-SOSA, Vanessa

\author{
Universidad Autónoma de Coahuila
}

ID $1^{\text {st }}$ Author: Temístocles, Muñoz-Lopez / ORC ID: 0000-0003-4940-5730, Researcher ID Tomson: T-7834-2018, CVU CONACYT ID: 202437

ID $1^{\text {st }}$ Coauthor: Jaquelina Lizet, Hernández-Cueto / ORC ID: 0000-0002- 3728-7434, Researcher ID Thomson: S-85882018, CVU CONACYT ID 322702

ID $2^{\text {nd }}$ Coauthor: Gabriela, Morán-Delgado / ORC ID: 000001-8433-4216, Researcher ID Thomson: X-2070-2018, CVU CONACYT ID: 306238

ID $3^{\text {rd }}$ Coauthor: Vanessa, Martínez-Sosa / ORC ID: 0000-0001-9442-8363, CVU CONACYT ID: 333696

DOI: 10.35429/JSEM.2019.19.6.5.10

Received July 02, 2019; Accepted December 29, 2019

\begin{abstract}
The main objective of this study is to develop a technique to evaluate the cognitive dispersion that exists in the contents and subjects of the curricula. The problem perceived by the authors is that learning is difficult when students have a greater diversity of subjects in their daily classes, when there are too many subjects per course or curricular axis and when they have fewer hours/class per day, which probably represents them greater cognitive complexity due to the dispersion of the contents to be learned. The experience of the authors in the design of the curricula has implied assessing the cognitive dispersion of multiple cases and the role of academic planners in systematically avoiding it. This research collects the methodology and experience of other studies in various areas and applies them in order to obtain a Cognitive Dispersion Index that allows us to evaluate this aspect when designing the study programs.
\end{abstract}

Curriculum, Curriculum trajectory, Cognitive dispersion, Study programs

\begin{abstract}
Resumen
El presente estudio tiene como objetivo central desarrollar una técnica para evaluar la dispersión cognitiva que existe en los contenidos y asignaturas de los planes de estudio. El problema percibido por los autores es que el aprendizaje se dificulta cuando los estudiantes tienen una mayor diversidad de asignaturas en sus clases diarias, cuando hay demasiadas asignaturas por trayecto o eje curricular y cuando tienen menos horas/clase al día, lo que probablemente les represente una mayor complejidad cognitiva debida a la dispersión de los contenidos por aprender. La experiencia de los autores en el diseño de los planes de estudio ha implicado valorar la dispersión cognitiva de múltiples casos y el papel de los planeadores académicos de eludirla sistemáticamente. Esta investigación recaba la metodología y la experiencia de otros estudios en diversas áreas y los aplica con el fin de obtener un Índice de Dispersión Cognitiva que nos permita evaluar este aspecto al diseñar los planes de estudio.
\end{abstract}

Curriculum, Trayecto curricular, Dispersión cognitiva, Plan de estudios

Citation: MUÑOZ-LÓPEZ, Temístocles, HERNÁNDEZ CUETO, Jaquelina Lizet, MORÁN-DELGADO, Gabriela and MARTÍNEZ-SOSA, Vanessa. Calculating Cognitive Dispersion of the curriculum. Journal of Systems and Educational Management. 2019. 6-19: 5-10

\footnotetext{
* Correspondence to Author (email: temistoclesmunoz@uadec.edu.mx)

$\dagger$ Researcher contributing as first author.
} 


\section{Introduction}

Cognitive dispersion is a concept that evokes and implies a diversity of topics that demand simultaneous attention during the learning process, and that for some people constitute complex schemes that are difficult to learn. However, many students are able to learn not only the knowledge of several subjects simultaneously, when they have a logical and psychological coherence and also have an understandable degree of atomization for their particular perception.

This is a topic that directly involves the planners and designers of the curriculum, as well as the teachers who plan their learning activities, or the students who need to integrate the knowledge that will be evaluated and will be part of their professional training.

The subject has been studied to understand the development and operation of business organizations seeking to give them a rationale to the management of their human resources and to positions that have been designed to improve quality and productivity. However, we believe that its principles can be adopted and adapted in schools.

If companies are organizations that produce goods, schools are also organizations that produce a service, through which people are formed for life and professionals to make a living. The objective of this research is to establish the bases to develop a technique that measures the cognitive dispersion of the curricula with simplified indices, which allows them to be compared, and proposes the alternatives to reduce this dispersion by making the coherence, congruence and relevance of the students more affordable. learning from the organization and curricular alignment of academic programs. This work, therefore, aims to apply the concept of "Cognitive Dispersion" to education, training and academic training.

\section{Theoretical perspective}

The dispersion, according to Helena Pingarrón, of http://etimologias.dechile.net, comes from the Latin dispersed (action and effect of dividing and spreading), names the action of the verb dispergere (spreading, undoing, throwing to one side and the other). This concept needs to be controlled if we want to increase the quality of academic programs and learning processes.
The authors emphasize that the basic axes of sustainability and sustainability of the quality of higher education lie in the transformations of the matrices of knowledge organization, academic organization and learning organization, forming platforms that are linked in each of the academic management processes (Larrea De Granados, 2015).

Complexity normally includes the degree of internal segmentation "(..) which includes the number of separate parts of the organization that reflect the division of labor, the number of hierarchical levels and their scope of dispersion" (in: "Organizational Size, Complexity , and Formalization "(Hall, Haas, \& Johnson, 1967)). These authors suggested a set of indicators of complexity.

The analysis of the didactic interaction in the classroom is carried out from two study traditions: the socio-ethnographic linguistic approaches and the socio-cognitive approaches. Exchanges according to their high or low cognitive requirement are significantly associated with mediation criteria and cognitive functions, raised by the model of mediated learning experience. The categories observed have conversational and cognitive significance, and are manifested in various ways throughout the duration of the class. (Villalta Páucar, Budnik, \& Valencia, 2013). According to the same authors, the work of Nathan and Kim (2009) operationalizes the levels of cognitive complexity according to the type of teacher intervention, and finds that the quality of student interventions guides the teacher on the level of cognitive complexity You can ask the student in his next interventions.

We can affirm that in many cases there is cognitive dispersion that induces a lack of coherence in the mentality of the students. For Abbagnano (Abbagnano, 1992), Coherence refers to the order, relationship, harmony of a knowledge system, and states that Kant attributed a priori knowledge to the task of ordering and coherence in sensitive representations. Thus, coherence has been considered as the criterion of truth, and that reality is an absolute consciousness that embraces, in the form of harmonious coherence, the multiple, dispersed and contradictory totality of the sensitive appearance. Consistency is not only the absence of contradiction, but the presence of positive relationships that establish a harmony between system elements. 
In other studies that seek clarifications in the cut-off criteria, the internal coherence of the subject programs has been investigated. Internal coherence is the logical articulation between the objectives or competences to be achieved, the methodologies for their development and the evaluation to certify achievement. The Internal Coherence Index seeks to elucidate the score to be considered consistent with the curricular model aimed at achieving competencies. (Manzano, Machuca, Cristina, Andrade, \& Coronado, 2010).

With this in mind, one of the central challenges for the institutions is to accredit the quality of the training offered, for this it is essential to achieve the coherence of the curricular design. It should be noted that the possibility of creating instruments arises from the need to advance in the systematic evaluation of the formal curriculum; as well as in the search of mechanisms that give greater reliability, providing timely and relevant information about the coherence of the curricular designs generated with guidelines and routes articulated with the stated purposes..(Castañeda, Castro Rubilar, \& Mena Bastías, 2013)

\section{Cognitive dispersion}

As in the Curriculum, the processes of generating alternative options and making strategic decisions are the product of mind maps subjectively constructed by decision makers and executors. The different agents of the organization, understood as a complex sociotechnical system (Levy, 2011), decide and operate through mind maps with which they "read" reality. The alignment of these mental maps, based on convergent communication aimed at reducing the cognitive dispersion of these agents, is the key to the execution of strategy and organizational learning (Levy, 2011).

In the organization of knowledge, following the same criteria of the previous author, as in each subsystem or unit of the organization, executes a part of the work or a set of tasks with different degrees of complexity, whose efforts are integrated by coordination mechanisms (integration vertical and horizontal) that help to achieve the effective performance of the organization as a whole.
Therefore, the success of an organization depends, in large part, on the appropriate levels of differentiation and integration necessary to meet the demands of the environment. Situation that leads, in many cases, to the design of more complex organizations. The document defines complexity as the structural unit where the members of the organization are grouped with the cognitive competence of each subject and is explained fundamentally through the behavior and management of the organizational design variables (Zapata \& Caldera, 2008).

Other authors have investigated the case of the loss of coherence due to curricular dispersion (Belletich Ruiz, Rodríguez Wilhelmi, \& Ángel Alvarado, 2016) and in another case, after approving the curriculum development regulations for secondary schools in Alicante, the Obvious institutional disagreement has been reflected in secondary school curricula that, in the case of Geography, represent a great disparity of criteria in the organization and distribution of curricular contents characterized by the disagreement, which has brought two consequences: the curricular dispersion, as well as the legal insecurity of the approved norms (Miguel González, 2016).

Also, in Duman and Aslan textbook research it was found that the taxonomically questions at the evaluation level corresponded to the Duman and Aslan knowledge and understanding levels. (2019); while in the field of vocational training, Myers, et al. (2019) significantly predicted higher levels of civic participation later in adulthood, especially for students who entered college with low levels of pro-civic orientation according to Myers, CB, Myers, SM, \& Peters, M. (2019).

In addition, Stowe, et al. They mention that more than a decade of research at the university level indicates that focusing instruction on scaffold progressions of core ideas can help students cultivate, organize and use their disciplinary knowledge to explain and model a variety of phenomena (Stowe, Herrington, McKay, \& Cooper, 2019)

Additionally, the results show that a longer curriculum is negatively related to the development of civic and political commitment (CPE), particularly in the lower part of the distribution. 
In addition, we found that the negative relationship between the duration of the curriculum followed and the CPE is mediated by tuition rates for Witschge higher education, and van de Werfhorst, H. G. (2019).

Now, the concept of Didactic Unit has evolved to the present day. The first approach to the concept of didactic unity was elaborated by Herbart (1822), who said that it is a consequence of the need to organize the subjects according to the development of thought. (Federation of Education of CC.OO. of Andalusia, 2010). This leads us to understand that the processes of generating alternative options and strategic decision making are the product of mind maps subjectively constructed by decision makers and executors with whom they "read" reality.

The alignment of these mental maps, based on convergent communication is aimed at reducing the cognitive dispersion of these agents, is the key to the execution of the strategy and organizational learning (Alberto Ramón, 2011).

In relation to the above, it is necessary to consider that, in their practical application, the authors have initially been inspired by "ECP Strategy, Cognition and Power" by Alberto Levy, where a calculation of the dispersion that is done by interpolation is introduced, taking note that by convention the minimum and maximum values are $0.50(\mathrm{p} / \mathrm{q})$ and 1 that correspond to the probability $\square$.

It is necessary to denote that in a professional work of the main author of this article, the problem discussed here was detected and a diagnosis of the current Academic Program had to be developed, the origin of this process of assessment of cognitive dispersion.

\section{Methodology}

To achieve the above, the research that proposes measures and formulas to measure cognitive dispersion in both productive organizations and schools was analyzed. Hence, these formulas were adapted with data related to the curricula and curricula, with tests being carried out in undergraduate and master's degree programs, which in many cases presented a large number of curricular paths or subjects that are distributed with inconsistent information and in others, with a coherent.
Pertinent and congruent distribution with the proposed objectives of the program and the profile of the planned graduate. The data were entered according to the formula defined in a spreadsheet in such a way that the values were recalculated to obtain a dispersion index, with which adjustments were made to obtain comparisons between the different programs looking for the causes of the alteration of the values obtained.

The data analyzed with the spreadsheet were simplified during the final calculations to prepare the proposal.

\section{Results}

The application in Academic Programs showed the following formulas, starting with a bachelor's degree, three face-to-face and three blended degrees that debugged the formula considering two sequential calculations:

1. Number of Courses per weekly period $=$ Number of courses or subjects / Duration of the Program per period of Academic Work either Semester, Quarter, Tetramestre etc.

2. Scattering Index $=$ (Number of Courses per week / Hours of academic work per week, includes independent study and internships) $*$ Number of curricular paths) $* 10$.

The results obtained were derived from a first study that was carried out in the Degree of Prevention and Control of Claims as a technical study that culminated in a redesign of the Curriculum.

\begin{tabular}{|l|r|r|r|}
\hline \multicolumn{1}{|c|}{ Criteria Lic. Bomberos Initia } & \multicolumn{1}{c|}{$\begin{array}{c}\text { Proposal } \\
\text { Improvement }\end{array}$} & \multicolumn{1}{|c|}{ Ideal } \\
\hline $\begin{array}{l}\text { Duration of the Program by } \\
\text { period of Academic Work: } \\
\text { Semester, Trimester, } \\
\text { Tetramestre etc .: }\end{array}$ & 10 & 10 & 10 \\
\hline $\begin{array}{l}\text { Weeks by Academic Work } \\
\text { Period }\end{array}$ & 16 & 16 & 16 \\
\hline $\begin{array}{l}\text { Hours of academic work per } \\
\text { week (includes independent } \\
\text { study and internships) }\end{array}$ & 27 & 40 & 40 \\
\hline Number of curricular paths & 13 & & \\
\hline $\begin{array}{l}\text { Number of courses per weekly } \\
\text { period }\end{array}$ & 9.3 & 5 & 5 \\
\hline Number of courses or subjects & 93 & 5.4 & 4.8 \\
\hline & 4.478 & 0.675 & 0.600 \\
\hline Scatter Rate $=$ & $44.78 \%$ & $6.75 \%$ & $6.00 \%$ \\
\hline
\end{tabular}

Table 1 Evaluation of the index of initial dispersion in the Degree of Prevention and Control of Claims and the adjustments achieved in the proposal that was made, and with a weighting that could be considered ideal 
Given the previous results, 6 private Master's degrees were developed, all with the same criteria, including Oral Trials, in International Finance, Education, Senior Management, Positive Psychology and Industrial Safety and, Environmental Protection,

\begin{tabular}{|l|r|}
\hline \multicolumn{1}{|c|}{ Criteria Masters U. of Saltillo } & Eval. \\
\hline $\begin{array}{l}\text { Number of periods of Academic Work (Semesters, } \\
\text { Quarters, Tetrameters, etc.) of the Program }\end{array}$ & 6 \\
\hline Weeks by Academic Work Period & 12 \\
\hline $\begin{array}{l}\text { Hours of academic work per week (includes } \\
\text { independent study and internships) }\end{array}$ & 27 \\
\hline Number of curricular paths & 3 \\
\hline Number of courses per week & 2 \\
\hline Number of courses or subjects & 12 \\
\hline & 0.22 \\
\hline Scatter Rate $=$ & 2.22 \\
\hline
\end{tabular}

Table 2 Where the analysis of 6 private Master's degrees, developed all with the same criteria, based on previous experience, including that of Oral Trials, in International Finance, Education, Senior Management, Positive Psychology and Industrial Safety and Environmental Protection, developed by the lead author of this study

\section{Conclusions}

It is clear the need to reduce the cognitive complexity of the curricula, not precisely removing content or reducing the level of teaching requirement, rather, optimizing the contents through adequate curricular alignment and reducing their cognitive dispersion to achieve coherence Internal program.

The proposed formula has worked because it is based on empirical evidence that leads to care for the basic elements of the design of educational programs to provide a balance in the academic load and better structuring of content.

It is highly recommended to build similar indicators or adjust the one proposed here to apply to asynchronous distance education. Surely, with the support of computer technology, a system can be developed to automate the calculation process in academic and institutional planning areas. We work on that today. Clearly explain the results obtained and the possibilities for improvement.

\section{References}

Abbagnano, N. (1992). Diccionario de Filosofía. México: Fondo de Cultura Económica.
Alberto Ramón, L. (2011). estrategy and cognition: the strategy execution process through cognitive alignment Estrategia y cognición: la ejecutabilidad de la estrategia a través del alineamiento cognitivo. AD-Minister, 5-20. Retrieved from http://pucrio.summon.serialssolutions.com/link/ 0/eLvHCXMwTZw_C4MwEMVDodCli9DmU yiaRHNZWytOUoqDm5icN5b-

8fvTJCJ0fLfccMfjhve7gAFXUhlyUhdkrZVVi W4SNgeDGhEgsM6XXtQDdLVu_9y8SdjOfk 6saW79tU1DPGx8rT8XxvAFORa2vNgoEJwD WSkHRErkqOeCSILSCpLaX-

FndpxCSvy5RJoMOduTH-

nMg81y35Kzw2DEoxvMfZXJJrNvRJ6y98K9q 8eNSIus_AG52Tot

Belletich Ruiz, O., Rodríguez Wilhelmi, M., \& Ángel Alvarado, R. A. (2016). La educación musical en la formación básica en España. El problema de la dispersión curricular. Perspectiva Educacional. Formación de Profesores. https://doi.org/10.4151/07189729VOL.55-ISS.2-ART.454

Castañeda, M. T., Castro Rubilar, F., \& Mena Bastías, C. (2013). Instrumentos para evaluar el currículum formal en carreras pedagógicas. PANORAMA.

https://doi.org/10.15765/pnrm.v6i10.27

Duman, E. Z., \& Aslan, G. (2019). An Investigation into the Logic Textbooks Written in Accordance with the 2009 Logic Curriculum. Asian Journal of Education and Training, 5(1), 166-175.

https://doi.org/10.20448/journal.522.2019.51.16 6.175

Federación de Enseñanza de CC.OO. de Andalucía. (2010). la unidad didactica, un elemento de trabajo en el aula. Temas Para La Educación.

Hall, R. H., Haas, J. E., \& Johnson, N. J. (1967). Organizational Size , Complexity, and Formalization. American Sociological Review, 32(6), 903-912. Retrieved from http://www.jstor.org/stable/2092844

Larrea De Granados, E. (2015). El Currículo De La Educación Superior Desde La Complejidad Sistémica. Consejo de Educación Superior. 
ejecutabilidad de la estrategia a través del alineamiento cognitivo. Revista Ad-Minister. Retrieved from https://ideas.repec.org/a/col/000475/011769.ht $\mathrm{ml}$

Manzano, M. M., Machuca, J. S., Cristina, M., Andrade, T., \& Coronado, S. P. (2010). Estudio de caso de la coherencia interna de programas de asignaturas en seis carreras que promueven competencias de la universidad austral de chile. Estudios Pedagógicos.

Miguel González, R. de. (2016). Geografía y currículo escolar en la ESO y el Bachillerato con la LOMCE: historia de un desencuentro. In Congresos - GeoAlicante 2015 - Libro de Actas. https://doi.org/10.14198/geoalicante2015.05

Myers, C. B., Myers, S. M., \& Peters, M. (2019). The longitudinal connections between undergraduate high impact curriculum practices and civic engagement in adulthood. Research in Higher Education, 60(1), 83-110.

Stowe, R. L., Herrington, D. G., McKay, R. L., \& Cooper, M. M. (2019). Adapting a Core-Idea Centered Undergraduate General Chemistry Curriculum for Use in High School. Journal of Chemical Education, 96(7), 1318-1326. https://doi.org/10.1021/acs.jchemed.9b00071

Villalta Páucar, M. A., Budnik, C. A., \& Valencia, S. M. (2013). Conocimiento escolar y procesos cognitivos en la interacción didáctica en la sala de clase. Perfiles Educativos, 35(141), 84-96. https://doi.org/10.1016/S01852698(13)71836-1

Witschge, J., \& van de Werfhorst, H. G. (2019). Curricular tracking and civic and political engagement: Comparing adolescents and young adults across education systems. Acta Sociologica, 0001699318818650.

Zapata, G., \& Caldera, J. (2008). La complejidad de las organizaciones. Ciencias Sociales, 14. Retrieved from http://dialnet.unirioja.es/servlet/articulo?codigo $=4243813$ 